\title{
BIOLOGICALLY ACTIVE SUBSTANCES OF FUNGUS ASPERGILLUS NIGER
}

\author{
Zhursinali A.B., Kurmanbaev A.A. \\ National Center for Biotechnology \\ 13/5, Korgalzhyn road, Nur-Sultan, 010000, Kazakhstan \\ Altynai_9700@mail.ru
}

\begin{abstract}
The filamentous fungus Aspergillus niger is frequently used for industrial production of fermentative products such as enzymes, proteins and biochemicals. In contrast to what most people might think, citric acid is not or not anymore isolated from citrus fruits, but is industrially produced by the filamentous fungus Aspergillus niger. In 1917, a food chemist named James Currie made a promising discovery: any strain of the filamentous fungus Aspergillus niger would produce high concentrations of citric acid when grown in sugar medium. This tricarboxylic acid, which we now know is an intermediate of the Krebs cycle, had previously been extracted from citrus fruits for applications in food and beverage production. Two years after Currie's discovery, industrial-level production using Aspergillus niger began, the biochemical fermentation industry started to flourish, and industrial biotechnology was born. Aspergillus niger additionally producing a diverse range of proteins, enzymes and secondary metabolites. In this review, we presented materials on more than 100 years of use of Aspergillus niger in biotechnological production of biologically active substances and environmental protection.
\end{abstract}

Key words: Aspergillus niger, citric acid, chitin, lipase, xylanase, alphaamylase, tensyuic acid.

\section{INTRODUCTION}

The modern level of biotechnology development makes it possible to widely use microorganisms for the synthesis of antibiotics, amino acids, polysaccharides, vitamins, carotenoids, organic acids and other substances. Currently, there is increasing interest in the biotechnological production of a number of chemical products and it is expected that the share of these processes will increase from $5 \%$ to $20 \%$ [1].

For millennia, humanity has practiced rudimental forms of biotechnology: by fermenting starch and sugars present in grains and fruits, ancient civilizations were able to produce bread, beer, wine, and other alcoholic beverages. Prior to the late nineteenth and early twentieth century, these processes were conducted without knowledge of the underlying biological events. Now, brewery and wine making is a well-understood, controlled industrial process. Similarly, in just a century, industrial biotechnology has changed dramatically and flourished, from initial proof-of-principle experimentation in Erlenmeyer flasks, to a multibillion dollar industry producing megatons of useful molecules. Fungal biotechnology is undoubtedly a major contributor and driver of this success. As just one example, the estimated market volume for plant degrading enzymes from filamentous fungi in 2016 was $€ 4.7$ billion, which was expected to reach up to $€ 10$ billion within the next decade [2]. 
The fungus Aspergillus niger is one of the significant microorganisms used in biotechnology. For many decades it has been used for the production of extracellular (food) enzymes and organic acids. In addition, A. niger is widely used for biotransformation and waste recycling. Kursanov L. I. called A. niger "biochemical frog" because of the variety of applications of its metabolites. This micromycete has been used in biotechnology for more than a hundred years.

Aspergillus niger belongs to the Ascomycetes class, Aspergillaceae family, Aspergillus genus, which currently has over 120 species. The body of the fungus consists of colorless, highly branched and intertwined thin threads that form the mycelium [3]. A. niger is classified as a safe production organism [4].

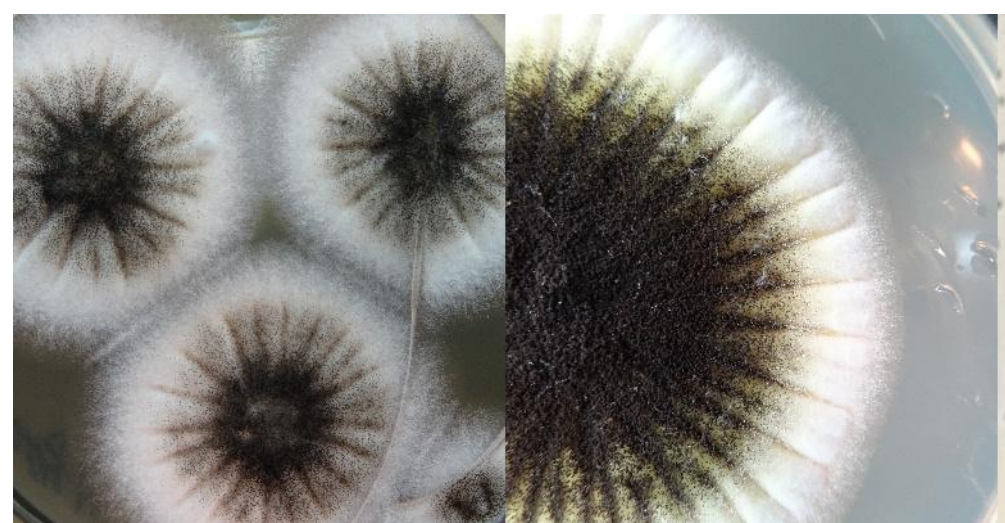

A

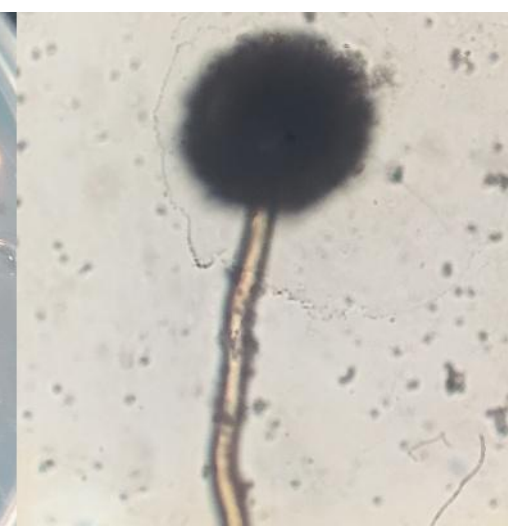

B

Fig. 1. Colonies and micrographs of mycelium of micromycetes Aspergillus niger. (authors' photos)

A - pure culture of Aspergillus niger; B - mycelium of Aspergillus niger

Many species of Aspergillus sp. have great economic importance, which are associated with their use in industry for the production of organic acids and enzymes: $\alpha$ amylase, protease, L-asparaginase, etc. [5].

A. niger is the most versatile filamentous fungal platform strain which can now be exploited to produce acids, proteins, enzymes, and medicinal drugs (table 1).

Table 1. Selection of (multi) national companies exploiting A. niger for the production of important industrial compounds [6].

\begin{tabular}{|l|l|l|}
\hline \multicolumn{1}{|c|}{ Company } & \multicolumn{1}{c|}{ Headquarter } & \multicolumn{1}{c|}{ Products } \\
\hline Adcuram & Germany & Citric acid \\
\hline AB Enzymes & Germany & Glucoamylase \\
\hline ADM & USA & Citric acid \\
\hline Agennix & Germany & Lactoferrin \\
\hline Amano Enzyme Co. Ltd. & Japan & $\begin{array}{l}\beta \text {-Galactosidase, Glucoamylase, } \\
\text { Glucose oxidase, Hemicellulase, } \\
\text { Proteases }\end{array}$ \\
\hline Anhui BBCA biochemical & China & Citric acid \\
\hline BASF & Germany & Hemicellulase, Phytase \\
\hline Biocon & India & Cellulase, Hemicellulase, Pectinase \\
\hline $\begin{array}{l}\text { Cangzhou kangzhuang } \\
\text { chemical }\end{array}$ & China & Glucoamylase \\
\hline Cargill & USA & Citric acid \\
\hline Christian Hansen & Denmark & Chymosin \\
\hline COFCO & China & Citric acid \\
\hline DSM & The Netherlands & $\begin{array}{l}\text { Arabinase, Asparaginase, Catalase, } \\
\text { Cellulase, } \beta \text {-Galactosidase, } \\
\text { Glucoamylase, Glucose oxidase, }\end{array}$ \\
\hline
\end{tabular}




\begin{tabular}{|l|l|l|}
\hline & & $\begin{array}{l}\text { Hemicellulase, Lactoferrin, Lipase, } \\
\text { Pectinase, Phytase, Proteases, } \\
\text { Xylanase }\end{array}$ \\
\hline Dupont IB & The Netherlands & $\begin{array}{l}\text { Catalase, } \beta \text {-Galactosidase, } \\
\text { Glucoamylase, Glucose oxidase, } \\
\text { Hemicellulase, Lipase, Pectinase }\end{array}$ \\
\hline Dyadic & USA & $\begin{array}{l}\text { Cellulase, Glucoamylase, Glucose } \\
\text { oxidase }\end{array}$ \\
\hline Gadot Biochemical Industries & Israel & Citric acid \\
\hline Genencor INT & USA & $\begin{array}{l}\text { Cellulase, Hemicellulase, } \beta \text { - } \\
\text { Galactosidase }\end{array}$ \\
\hline Haihang Industry & China & Cellulase \\
\hline Iwata Chemical Co. Ltd & Japan & Citric acid \\
\hline Jungbunzlauer & Switzerland & Citric acid \\
\hline Mitsubishi Foods Co. Ltd. & Japan & Proteases \\
\hline Megazyme & USA & Catalase, Inulinase, Glucosidase \\
\hline Novozymes & Denmark & $\begin{array}{l}\text { Asparaginase, Catalase, } \beta \text { - } \\
\text { Galactosidase, } \\
\text { Glucoamylase, Hemicellulase, } \\
\text { Lipase, } \\
\text { Pectinase, Phytase, Proteases }\end{array}$ \\
\hline Shandong longda bio-products & China & Glucoamylase, Pectinase \\
\hline Shin Nihon Chemical Co. Ltd. & Japan & $\begin{array}{l}\text { Arabinase, Catalase, Cellulase, } \\
\beta \text {-Galactosidase, Hemicellulase, } \\
\text { Proteases }\end{array}$ \\
\hline Verenium & UK & Citric acid \\
\hline Glucoamylase, Proteases \\
\hline
\end{tabular}

Aspergillus niger as a producer of organic acids. The first reports of the production of organic acids by fungi belong to the second half of the XIX century. In 1877, Hamlet and Plevritom established ability of fungi to biosynthesis of oxalic acid. In 1891, the German scientist Karl Wamer established the formation of oxalic acid in Aspergillus niger [7].

Organic acids, which obtained microbiologically, are an important group among chemical products. Organic acids and their salts are widely used in food, chemical, pharmaceutical and other industries. The ability of a number of organic acids to polymerize makes it possible to obtain numerous synthetic materials that have valuable properties and widely usage. By microbial synthesis in the present time, it would be possible to obtain about 60 organic carboxylic acids. In microbiological synthesis, unlimited, constantly renewable resources are used - plant raw materials, waste from the forest and agricultural industries, waste from the production of biodiesel. In addition, microorganisms can produce optical isomers, which is very important in the synthesis of physiologically active substances for the food industry and health care [8].

Among organic acids the most popular are citric, oxalic, acetic, gluconic, lactic, itaconic and succinic acids.

US scientists Catherine Brown and Joe Harrison found that the production of oxalic acid from Aspergillus niger is possible by using lactose as a carbon source instead of glucose or sucrose. The use of glucose or sucrose as a substrate at high $\mathrm{pH}$ values leads to the formation of predominantly gluconic acid. While they were using serum, which from casein proteins were removed and enriched with lactose, the fungus formed a large amount of oxalic acid [9]. 
Gluconic acid is widely used in food, feed, pharmaceutical, cement, textile and chemical industries. The demand for gluconic acid is about 50000-60000 tons per year and is growing from every.

Many studies have been conducted to improve the production of gluconic acid from Aspergillus niger [10]. Unlike other acids, this acid is synthesized mainly extracellularly. In the first stage, glucose is oxidized by the enzyme glucose oxidase to D-glucono-1,5-lactone. The hydrolysis of lactone to gluconic acid can occur spontaneously in an aqueous solution, but the rate of this reaction increases significantly under the action of the enzyme gluconolactonase. Both enzymes are considered to be localized outside the plasma membrane, however, it has recently been shown that in $A$. niger has a gene encoding and intracellular glucose oxidase [11].

Gluconic acid, is a substrate lightly metabolized by fungi, and can be used as a carbon source. Two gluconate-specific kinases have been identified in Aspergillus niger and it is assumed that gluconic acid catabolism occurs through its phosphorylation to 6P-gluconate. Next, 6-P-gluconate is included in the pentose phosphate cycle [12 ].

The formation of malic acid, like fumaric acid, can occur in mitochondria or in the cytoplasm. In the cycle of tricarboxylic acids, fumaric acid under the action of the enzyme fumarase attaches water and turns into malic. Further, malic acid under the action of the enzyme malate dehydrogenase is oxidized to oxalic acid to form NADH. Fungi are assumed to have three cytoplasmic and one mitochondrial malate dehydrogenases. The production of malic acid in the substratum is noted for the fungi Aspergillus spp., Penicillium spp. and Rhizopus oryzae [13].

Malic acid production from the Aspergillus niger strain is generated in a solid medium containing methanol and malic acid, in an adaptation process for 22 weeks. The yield of malic acid was increased by 4.45 times compared to the yield of the original strain and of Penicillium spp. and Rhizopus oryzae [14].

In 2019, scientists from France isolated phenolic acids from sunflower and rapeseed meals with the use different carboxylic esters hydrolases from Aspergillus niger.

Phenolic acids are derivatives of aromatic hydrocarbons, in the molecules of which the hydrogen atoms of the benzene nucleus are replaced by carboxyl and hydroxyl groups. They are sometimes considered as aromatic acids, in the molecules of which the hydrogen atom of the benzene nucleus is replaced by hydroxyl groups.

Phenolic acids have a bactericidal effect. Its salts and esters are widely used in medicine and veterinary medicine as medical products. Salicylic acid is widely used for the production of medicines, mordant dyes, fungicides, odorous substances, antiseptics in the food industry, in canning, as a reagent for colorimetric determination in solutions of iron and copper, as an acid-base indicator in fluorescent analysis [15].

Aspergillus niger also produces itaconic acid due to its versatile and tolerant nature in various growth environments and its extremely high ability to accumulate an itaconic acid precursor [16].

Itaconic acid $\mathrm{C}_{5} \mathrm{H}_{6} \mathrm{O}_{4}$ is an unsaturated dibasic acid [17]. It is necessary to modify the genome and optimize the environment for cultivation to increase the level of its production. The level of production of itaconic acid is positively related to the concentration of copper in the medium. A. niger is the most resistant to copper, especially in low $\mathrm{pH}$ conditions, this allow the use of copper to increase the production of itaconic acid in this species. In addition, copper ions can increase citric acid production [18].

Citric acid is a white crystalline substance, natural or synthetic antioxidant. Citric acid is an important metabolic product in living organisms, involved in the tricarboxylic acid cycle and the glyoxylate cycle. The volume of the world market of citric acid in 
2016 amounted to 2.50 billion dollars. High demand for food storage products is expected to be a key driver of industry growth [19].

Large amounts of citric acid are used in food production (70 \%), pharmaceutical and other industries. Citric acid - widely used acidity regulator for the food industry, has a softer taste compared to other food acids and does not irritate the mucous membranes of the respiratory and digestive tract. Therefore, most citric acid is supplied to the production of various beverages-carbonated, non-carbonated soft drinks, tonic, dry drinks, cold teas. Citric acid is widely used in confectionery and bakery industries, canning industry, as well as in the production of sauces, ketchup, mayonnaise, processed cheeses and frozen foods. As a preservative, citric acid is used to increase the approximately of meat, jelly and preserves. Approximately $15-17 \%$ of the citric acid produced in the world is used in the production of detergents, as a substitute for polyphosphates and its share in this sector will only increase. In the cosmetic and pharmaceutical industries-7-9 \% and another 6-8\% goes to other industries: oil production, animal husbandry, metallurgy, construction, production of paints, textiles, photographic reagents, concrete, gypsum, refractory and molds, adhesives, paper, polymers, tobacco, waste disposal, activation of mineral fertilizers, etc. [20].

Aspergillus niger as a source of chitin. Natural biopolymer chitin is called the product of the XXI century. The main source of this polymer is shellfish, insects and fungi. The cell wall of the fungus Aspergillus niger, which is a producer of citric acid and a waste product of its production, contains $20-25 \%$ chitin.

Aspergillus niger produces 13,500 tons of wet mycelium per year as a byproduct in the production of citric acid, which can be a beneficial source of chitin and chitosan [21].

Chitin $\left(\mathrm{C}_{8} \mathrm{H}_{13} \mathrm{NO}_{5}\right)_{\mathrm{n}}$ is a natural compound from the group of nitrogen-containing polysaccharides. The chemical name is poly-N-acetyl-D-glucose-2-amine, a polymer of n-acetylglucosamine residues bonded together by $\beta-(1,4)$ - glycoside bonds. Beta$1,3 / 1,6$-glucans are natural carbohydrates found in the cell walls of yeast, bacteria and fungi (the latter two also contain the main component of the exoskeleton (cuticle) of arthropods and a number of other invertebrates). Chitin increases nonspecific and specific immunity by identifying and stimulating macrophages, t-killers, t-helpers and NK cells; the rate of maturation of immunocompetent cells and very significantly increases their life span. Chitooligosaccharides show antitumor and immunostimulatory properties, enhance plant growth, inhibit the reproduction of parasites. Chitin is also used to create non-pyrogenic surgical sutures, contact lenses, artificial skin. In medical institutions with the help of chitin and its derivatives heal burns, wounds and ulcers (regeneration time is reduced by $75 \%$ ). Chitosan is used in medical practice (for example, for the treatment of stomach diseases; chitosan membranes are in devices such as "artificial kidney"), in food technology are used as a thickener and structuring agent in the production of mousses, jellies, juices, etc. It can also be used to reduce acidity and lighten fruit juices. When chitosan is added to dairy products, their shelf life increases. It is possible to use chitosan in the extraction of radionuclides from the wastewater of nuclear reactors and other liquids contaminated with radioactive substances. Fundamental research in the field of chitin and chitosan is carried out in Russia. Thus, new aspects of practical application of these biopolymers have been found. Results on interaction of chitosan with proteins and nucleic acids, antiviral and antitumor effect of its derivatives, creation of micro-and nanoparticles of different structure, a wide variety of chitosan-containing preparations (for plant protection, veterinary, cosmetics, food additives, dietary Supplements) were obtained. Chitin and chitosan have high physiological activity. Chitin has a high sorbing activity and is able to purify wastewater from various anions [22]. 
Aspergillus niger is an enzyme producer. Aspergillus niger is a known producer of many commercial enzymes. At enzymes that catalyze the hydrolysis of carbohydrates in an acidic environment is increasing. This type of enzyme includes invertase (synonyms: $\beta$-fructofuranosidase, sucrose; class of hydrolases). It catalyzes the hydrolysis of $\beta$-D fructofuranosides, including sucrose, to D-fructose and glucose. This enzyme is used in different areas of the food industry. In confectionery production, it is used to create casting and round fondant candy shells, liquid fruit fillings. Invertase helps to prevent crystallization of sugars, slow down the fermentation process when using high concentrations of sugar in confectionery products, stabilize the consistency, enhance the taste, prolong the shelf life of the finished product. It is necessary in the preparation of invert syrups in the liquor and alcohol industry. The enzyme can also act as an anti-crystallizer in the manufacture of condensed milk, fruit drinks, juices, extracts, artificial honey and jam [23].

In 1787, "fermentation" of gall nuts using Aspergillus niger was described producing the enzyme tannase, with the formation of gallic acid, which is used in paints, inks, some pharmaceutical preparations.

The main directions of industrial application of tannase are food, pharmaceutical and chemical industries. An important application of tannase is the production of gallic acid. Gallic acid - the main product of tannin hydrolysis, is used in the food, cosmetic industry as a powerful antioxidant. It also serves as a precursor in the production of antimalarial drugs and as a light-sensitive resin in the production of semiconductors. It is reported about the anti-apoptic action of gallic acid, the ability to protect human cells from oxidative damage and cytotoxic action against cancer cells. Gallic acid is also used as a substrate in the enzymatic and chemical synthesis of propyl gallate, used as an antioxidant of fats and oils and in the beverage industry. The final product of gallic acid metabolism-pyrogallol, has great industrial importance, is used in the coloring of skin and fur, the manifestation of photographs, in the production of antitumor drugs. The practical use of tannase is still quite limited due to insufficiently studied its properties, the complexity of obtaining and purification. For industrial production, microorganisms are more used to produce an enzyme, than plant or animal because of its stability [24].

Lipases are widely found in bacteria, yeast and fungi [25]. In recent years, studies of microbial lipases have intensified due to their practical application in industry, in the hydrolysis of fats, production of fatty acids and food additives, synthesis of esters and peptides, resolution of racemic mixtures or addition to detergents [26].

Aspergillus niger is one of the best known lipase producers. Lipases catalyze the hydrolysis of acyl glycerol to fatty acids, diacylglycerides, monoacylglycerides and glycerin. Under certain conditions, they also catalyze the synthesis of esters by transesterification, thioesterification, and aminolysis.

The cell wall of plants consists of cellulose and hemicellulose. Interest in the destruction of these most abundant plant polymers is growing due to their cheapness and the possibility to use them to produce biofuels: biodiesel, bioethanol and biobutanol.

The Aspergillus niger genome contains a complete set of cellulolytic genes, but $A$. niger does not grow well on fiber. During growth on plant biomass, A. niger secretes high levels of $\beta$-glucosidase and low levels of cellobiohydrolase and $\beta$-1,4endoglucanase compared to Trichoderma reesei.

$\beta$-Mannanases are found in various organisms including bacteria, yeasts, and filamentous fungi. Aspergillus is an important mannanase producer. One of the plant polysaccharides are mannans, the main chain of which consists of $\beta$--mannose residues. Mannan is used in various biotechnology fields such as feed production, paper processing and coffee extract processing. 
$\beta-1,4-$ Mannans are major components of hemicellulose in the plant cell wall of softwood, plant seeds and beans. Four types of polysaccharides including linear mannan, galactomannan, glucomannan, galactoglucomannan that are linked via $\beta-1,4-$ glycosidic bonds constitute the plant mannans. Mannan hydrolysis provides a wide array of biotechnological applications in various areas such as feed manufacturing, paper process, and coffee extract treatment. A set of enzymes are required for complete degradation of mannans, including endo- $\beta$-1,4-mannanase, exo- $\beta$-mannosidase to cleave the main chain, and $\beta$-glucosidase, $\alpha$-galactosidase and acetyl mannan esterase to remove side chain decorations. Among these enzymes, $\beta$-mannanase, which catalyzes random hydrolysis of manno-glycosidic bonds in the main chain, is the key enzyme. More recently, the major products of $\beta$-mannanase, the mannooligosaccharides, have been indicated beneficial as animal nutrition additives due to its potential prebiotic properties. Since industrial process is usually carried out at high temperatures, stable enzyme usage under a broad range of temperature is highly desirable. In order to meet these demands, identifying thermophilic mannanases from various sources is of great interest. $\beta$-mannanase is able to decompose mannans into smaller sugar components [27].

Indian scientists from the biochemistry laboratory of the University of Lagos synthesized a new extracellular xylanase from Aspergillus niger.

Xylanase is an enzyme that cleaves the polysaccharide beta-1,4-xylan to xylose. Xylose is the building block of hemicellulose of some plants.

Xylanase is a complex of enzymes involved in the degradation of heterogeneous polysaccharide - xylan. The main enzyme is endo-1,4-xylanase, which catalyzes the breakdown of xylan to xylooligosaccharides. Xylan is a major component of lignocellulose biomass and is the second most abundant polysaccharide on earth

The enzyme is actively studied for the development of optimal methods of production in large amounts and biotechnological applications (use for hydrolysis of cellulose, sugars as a thermostable analogue of cellulase), use in medicine as part of preparations to improve digestion, in the food industry-for the production of bread. It has great importance for the paper, food and textile industries, for the production of biofuels. Xylanase lowers the viscosity of the contents of the small intestine, promotes the absorption of nutrients, and by increasing the conversion of feed increases the average daily gain of birds, xylanase also contributes to the destruction of plant cell walls and translates nutrients into digestible form. Xylanase increases the rate of feed promotion in the intestine, improves the microflora of the digestive tract, reduces the presence of pathogenic fungi and bacteria.

The xylanase-producing strain Aspergillus niger was isolated from a soil sample of Baramura forest, West Tripura, India. Xylanase production from Aspergillus niger using agricultural waste was monitored at 24-hour intervals over a 168 -hour period in media containing various carbon sources. Carbon sources were oat spelt xylan and sawdust, sugarcane pulp and wheat bran. The highest level of xylanase activity was obtained with wheat bran [28, 29].

Pectinases form a group of enzymes that break down pectin substances, which are structural polysaccharides present in plant cells and are responsible for maintaining the integrity of plant tissues [30]. Pectinases are a heterogeneous group of enzymes that decompose pectin. The production of pectinases by the fungus Aspergillus niger using powdered peel of citrus fruits was studied. The fungus produces pectinases extracellularly in the fermentation medium. The pectin present in citrus peel acts as an inducer for the production of pectinases. It was found that solid-phase fermentation gives maximum enzymatic activity with untreated substrate. 
Mushroom pectinases are used to lighten fruit and berry juices, to increase the yield of grape juice in winemaking, in the production of coffee. Pectinases are also used in the production of various fruit jellies [31].

Proteases from microorganisms have attracted much attention in the last decade because of their biotechnological potential in various industrial processes such as detergents, textiles, leather, dairy and pharmaceuticals. Proteases do not refer to a single enzyme, but to a mixture of enzymes that include proteinases, peptidases, and amylases. They have high temperature resistance with high specific activity and excellent physical and chemical characteristics that appear good for future biotechnological applications, so they are widely used in a large number of industrial processes. The sources of proteases are plants, animal tissues, and microorganisms, but due to the low production of proteases from the above sources, they are mainly produced by microorganisms that include fungi, bacteria, and some other microorganisms.

Proteases, also known as proteinases or proteolytic enzymes, occur naturally in all organisms and belong to the class of enzyme hydrolases [32].

Aspergillus niger is used in the production of alkaline protease. A strain producing alkaline protease Aspergillus niger was isolated from local soil samples and enzyme production was optimized under immersion conditions. The extracellular alkaline protease is purified from $A$. niger in a two-step procedure involving ammonium sulfate deposition and column chromatography. The alkaline protease isolated from $A$. niger is a serine protease. It is stable at an alkaline $\mathrm{pH}$ of 8-9 and a temperature of 27$37^{\circ} \mathrm{C}$. Alkaline proteases are used in the washing industry [33].

Also, Aspergillus niger isolated from the soil is able to produce acid protease. Proteases hydrolyze peptide bonds of proteins into peptides and amino acids, they are found in all living organisms, and essential for cell growth and differentiation. Proteases can be produced in large amounts in a short time using established fermentation techniques. Protease production was carried out using submerged fermentation, as well as in solid-phase fermentation [34].

Diabetes mellitus is considered one of the most serious medical and social problems of the present time. The increase in morbidity is epidemic in nature, increasing tenfold the risk of severe complications. In this regard, the development and active implementation of advanced methods of blood glucose control is of paramount importance. Biosensor systems meets the requirements for devices for clinical diagnosis, personalized therapy and individual use. There are both stationary laboratory glucose analyzers and portable systems consisting of a device-glucometer and test strips and allowing measure at home. Indicator test strips - enzyme preparation that are involved in biosensor systems for the determination of glucose, glucose dehydrogenase and glucose oxidase. The method of measuring blood glucose by test strips is based on the enzymatic reaction of glucose oxidation by glucose oxidase to gluconic acid and hydrogen peroxide. Under the action of gluconic acid in the presence of the enzyme peroxidase, chromogen oxidation occurs and the formation of a colored compound of the sensor element. The degree of chromogen conversion and the intensity of color of the indicator element of the test strip is proportional to the concentration of glucose [35]. The enzyme glucose oxidase is derived from Aspergillus niger.

Glucoamylase is an enzyme drug also produced by Aspergillus niger. It is used for saccharification of starch, pre-liquefied enzyme alpha-amylase, in the production of alcohol from grain and other starch-containing raw materials.

Alpha-amylase (1,4- $\alpha$-D-glycan-glucanohydrolase, glucan-1,4- $\alpha$-glucosidase, amyloglucosidase, Exo-1,4- $\alpha$-glucoadase, glucoamylase, lysosomal $\alpha$-glucosidase) cleaves the last $\alpha-1,4-$ glycosidase, leading to the formation of glucose. In addition, $\gamma$ amylase is able to hydrolyze, $\alpha-1,6$-glycoside bond. Unlike other amylases, $\gamma$-amylase is most active in acidic conditions (at $\mathrm{pH}=3$ ). The addition of amylase to the dough 
allows the yeast to use part of the flour starch for life, thereby accelerating the fermentation process, and at the same time allows the bread manufacturer to save sugar [36].

Phytases were first marketed in 1991 and are used to improve the nutritional value of animal feed by generating inorganic phosphorus from phytic acid, which is the main form of organic phosphorus in plant seeds. The market for biotech phytase production is estimated at 150 million euros per year, with A. niger being one of the most commonly used producers. Phytase from Aspergillus niger increases phosphorus availability from single-chamber stomach animal feed by releasing phosphate from the phytic acid substrate. The specific phytase activity in the isolated extracellular fluid was found to be about 90 times higher than in the General leaf extract. Despite the differences in glycosylation, the specific activities of tobacco phytase and phytase from Aspergillus niger were identical [37].

Inulooligosaccharides are an important class of oligosaccharides on an industrial scale. The effective conversion of inulin to inulooligosaccharides via endoinulinase from Aspergillus niger was found. The maximum activity of recombinant endoinulinase, $858 \mathrm{U} / \mathrm{ml}$ was obtained after 120 hours of fermentation process with high cell density.

Inulin $\left(\mathrm{C}_{6} \mathrm{H}_{10} \mathrm{O}_{5}\right) \mathrm{n}$ is an organic substance from the group of polysaccharides, a polymer of $\mathrm{D}$-fructose. The formula of the inulin molecule is shown in the fig. 2.

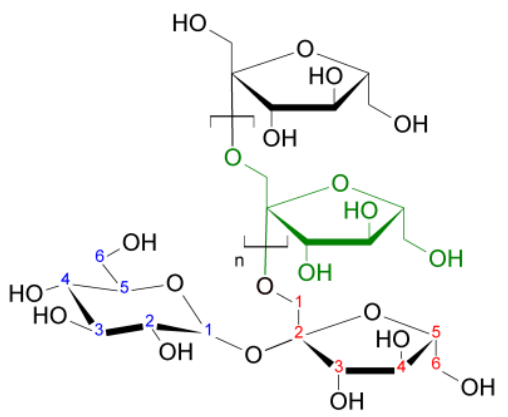

Fig. 2. Structure of inulin molecule [38].

From inulin under the action of the enzyme endoinulinase from Aspergillus niger, fructose can be obtained, etc.

Inulin is a good technological ingredient in the food industry. Inulin forms a fatlike texture and thus mimic the presence of fat in fat-free products, providing them with the fullness of taste inherent in products of normal fat content $(1 \mathrm{~g}$ of fat is replaced by $0.25 \mathrm{~g}$ of inulin). Due to the reduction of fat content, the caloric content of products is reduced. The texture of the product improves without compromising the taste. Inulin improves the stability of aerated products and emulsions.

In cosmetology, inulin is used in the manufacture of liquid soap, shampoos, emulsion gels, salts and foam for shower and bath, etc., forming a light film with a pleasant feeling on the surface of the skin and hair [39].

In nature laccase and laccase-like enzymes are widely distributed that are involved in the synthesis of lignin in plants, decomposition of lignin by fungi in detoxification processes, oxidative stress in the pathogenesis of plant growth and development rhizomorph, the synthesis of precursors of melanin and other phenomena.

Laccase is a representative of the oxidoreductase class, contains four copper ions in two active centers and catalyzes the one-electron oxidation reaction of substrates such as reduced phenols and their derivatives or aromatic amines. The process of oxidation of substrates is accompanied by the addition of four electrons to molecular oxygen and its reduction to water. A typical enzyme reaction cycle converts one oxygen molecule into two water molecules, with 4 substrate molecules oxidized. As a result of the reaction, 
some substrates may dimerize or polymerize. As a substrate, various phenols, aromatic amines and even metal ions can act.

Laccases are used in biotechnological processes such as bioremediation and detoxification of contaminated soils and effluents, organic catalysis, production of synthetic fibers from wood. They are also used in the food and brewing industry to improve the properties of the dough, improve the taste of beer and extend the shelf life of juices by inhibiting the oxidation of polyphenols in them. Laccases are well known as components of hair dyes and also add a preparation for bleaching cotton fabrics in the textile industry. Laccases are also used as cleaning agents for some water purification systems, as catalysts for the production of anti-cancer drugs, and even as ingredients in cosmetics [40].

Laccases exhibit broad substrate specificity and are capable of oxidizing polyphenols and polyamines, o - and $\mathrm{p}$ - diphenols, aminophenols, aryldiamines, ferrocyanides, and some inorganic ions. Due to these abilities, laccases are widely used as tools in biotechnology, in particular, in the bio-purification of industrial dyes and pesticides, in the paper industry, the production of bioethanol, wine and textile industries, in the production of cosmetics, for Biocatalysis and biological analyses [41].

Enzyme keratinase is a specific type of proteolytic enzymes, with the possibility of hydrolase of insoluble keratin. Keratinase is a promising drug and is used in various areas where keratin hydrolase is needed, for example: in the production of bioactive peptides, in the biomedical and pharmaceutical industries. In cosmetology, keratinase is successfully used to eliminate the keratinized layer on the skin in acne or psoriasis, eliminate calluses and reduce keratinized parts of the skin. Keratinase reduces the appearance of callus. Keratinase is obtained biotechnologically from bacteria and fungi. Due to the specific keratolytic activity of keratinase exfoliates dead skin cells very gently, without traumatic effects.

Researchers at the University of Brazil identified the synthesis of keratinase by $A$. niger mutants during solid-phase fermentation, and used agro-industrial residues to decompose keratin. Keratin is an insoluble structural protein resistant to hydrolysis by common proteolytic enzymes such as trypsin, pepsin, and papain [42].

Aspergillus niger is a producer of antibiotics, vitamins and toxins. Strains of Aspergillus niger group are able to synthesize vitamins biotin, thiamine, riboflavin, etc.

Aspergillus niger is a biochemically active fungus, some strains synthesize vitamins-biotin, B1, B2, the antibacterial drug fumagillin for the treatment of amoebic dysentery, other drugs [43].

Aspergillus niger is one of the most common fungi responsible for spoilage of products and biological destruction of materials, also has a significant impact on food safety due to the production of mycotoxins. Mycotoxins are secondary metabolites of microscopic fungi with toxic properties. There is every reason to believe that these secondary metabolites can perform numerous functions aimed at ensuring the survival of microscopic fungi and their competitiveness in the struggle for a place in various ecological niches.

Aspergillus niger is known to produce mycotoxins ochratoxin A, fumonisins B2, B4 and B6, as well as many other compounds with poorly understood activity.

Ochratoxin A is often present in foods. Contamination of food products, such as cereals and products based on them, coffee beans, raisins, wine and grape juice, spices and liquorice, is a widespread phenomenon throughout the world. Ochratoxin A is produced during storage of the crop. It is known to have Toxicological effects on animals. The most serious and noticeable effect is kidney damage, but this toxin can also negatively affect fetal development and the immune system. Despite of irrefutable data on the toxicity of ochratoxin A to the kidneys and its ability to cause kidney cancer 
in animals, there is no clear evidence of its similar effects on humans. However, there is some evidence of toxic effects of ochratoxin A on human kidneys [44].

Fumonisins are toxins of natural origin produced by some species of fungi of the genus fusarium. Many types of fumonisins are known, but the most commonly found in foods are fumonisins B1, B2 and B3 . Fumonisins were first discovered in 1988. Fumonisins can cause serious harm to the health of livestock and other animals. Although the evidence on the harmful effects of fumonisins on human health is not conclusive at the moment, it is suspected that exposure to fumonisins can lead to the development of a number of serious pathologies, such as cancer and birth defects.

In 2017, the China National food safety risk assessment center identified the production of fumonisin B2 in Aspergillus niger. The production of fumonisin from Aspergillus niger, which is a widespread species and an extremely important industrial organism, will have very important implications for biotechnology and especially food safety. A. niger produces fumonisin B2 on media with a large amount of sugar [45].

Scientists at Kitasato University in Japan have identified tensyuic acids from Aspergillus niger. Tensyuic acid is the first derivatives of itaconic acid that have ester carboxylic fragments at the end of the alkyl side chain. Aspergillus niger synthesizes 6 species of tensyuic acid from $\mathrm{A}$ to $\mathrm{F}$, among which acid $\mathrm{C}$ has antibiotic activity (fig. 3 ).

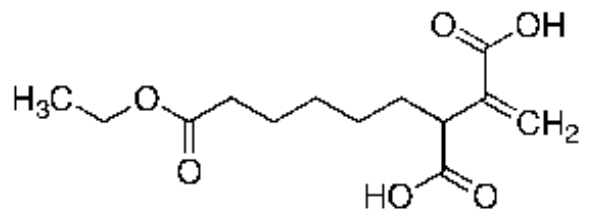

Tensyuic acid C

Fig. 3. Structure of tensyuic acid C

Tensyuic acid $\mathrm{C}$ showed moderate antimicrobial activity only against $B$. subtilis (inhibition zone: $10 \mathrm{~mm}$ at $50 \mathrm{mg} /$ disk). All the other tensyuic acids showed no inhibition zone against the microorganisms tested at $50 \mathrm{mg} /$ disk. A new antibiotic produced by Aspergillus niger was identified [46].

Using of Aspergillus niger culture in environmental protection. Aspergillus niger are used to extract heavy metals from a variety of solid waste, such as fly ash from municipal solid waste incinerators, spent catalysts, electronic waste and red sludge. The activity of Aspergillus niger has been evaluated to detoxify and recover the metals $\mathrm{Cu}$, $\mathrm{Li}, \mathrm{Mn}, \mathrm{Al}, \mathrm{Co}$, and $\mathrm{Ni}$ from spent lithium-ion mobile phone batteries under various conditions. The results showed that the use of A. niger achieves a higher efficiency of removal of heavy metals than with chemical leaching [47].

Phenols are raw materials for various industries. This causes the presence of phenols and products of their transformation in natural reservoirs, where they fall with domestic wastewater and wastewater from oil refining, forestry, coke, aniline industry, etc. In surface waters, phenols occur in the dissolved state in the form of phenolates, phenolate ions, and free phenols, which in turn can enter into condensation and polymerization reactions, forming complex humus-like and other fairly stable compounds of varying degrees of toxicity. Discharge of phenolic waters into reservoirs and watercourses sharply worsens their general sanitary condition, affecting living organisms not only by its toxicity, but also by a significant change in the regime of biogenic elements and dissolved gases. The problem of complete purification of wastewater from dissolved organic substances, in particular phenols is important and at 
the same time difficult to solve. Aspergillus niger strains play an important role in solving this problem [48].

Researchers in Spain have studied the ability to clean using some fungi that reduce the phenol content in the sewage of the olive plant. Aspergillus niger has been capable of decomposing phenols in olive plant wastewater. As a result, $82 \%$ of the phenols were removed from the wastewater treatment process using Aspergillus niger [49].

Aspergillus niger is very sensitive to mineral sources of nutrition, so it is possible to use specially selected strains to determine the deficiency of certain elements in the soil (phosphorus, potassium, copper, etc.) and vitamins, which turned out to be much easier, more accurate and faster than chemical analyses.

From a practical point of view, the production of organic acids by fungi is considered as one of the most important factors in the destruction of various materials, such as books, historical monuments, etc.

At present, the problem of environmental pollution by waste of polymeric nature is acute. Due to the mass production of packaging materials and their widespread use in many areas of human activity (industry: construction, agriculture, automotive, household activities), there is an excessive accumulation of synthetic polymer materials in the environment, which causes the need for recycling of these compounds.

Aspergillus niger in the community of biodestructors deforms the amorphous part of the polymer-containing material and violates its crystallinity. Thus, there is a decrease in the laying density of the long chain of methylene groups that make up the polyethylene molecule, which leads to a decrease in strength and an increase in the elasticity of the material [50].

\section{CONCLUSION}

In that way, based on the literature review, we can say that currently Aspergillus niger is one of the most used producers of biologically active substances in the biotechnology industry and its potential has not yet been fully disclosed. Aspergillus niger is one of the key organisms involved in the next industrial revolution: the transition from fossil economy to bioeconomics.

In modern biology, A. niger can be used in synthetic biology to create mycotoxinfree isolates, network analysis for gene expression and metabolomics, enhanced coculture technology and genome editing of CRISPR-Cas9, synthesis of organic acids and study of enzymes.

\section{Acknowledgments}

This work was supported by the Ministry of Education and Science of the Republic of Kazakhstan (grant AP05132472).

\section{REFERENCES}

1 Cairns T.C., Nai C., Meyer V. How a fungus shapes biotechnology: 100 years of Aspergillus niger research. Fungal Biology and Biotechnology. 2018, vol. 5, no.13. pp. $1-14$.

2 Citric acid market size, share and trends analysis report by form (liquid, powder), by application, by region, competitive landscape, and segment forecasts, $2018-2025$. Available at: https://www.grandviewresearch.com/industry-analysis/citric-acid-market (accessed February 2018) 
3 Cairns T.C., Feuerstein C., Zheng X., Zheng P., Sun J., Meyer V. A quantitative image analysis pipeline for the characterization of filamentous fungal morphologies as a tool to uncover targets for morphology engineering: a case study using aplD in Aspergillus niger. Biotechnology for biofuels, 2019, vol. 12, no. 149. pp. 1147-1150.

4 Matovich-Purich I., Pecarski D., Jugovich Z., Jovichich D., Dordevich D., Maskovich P. Comparative study of some biochemical parameters of the fungi Mucor plumbeus, Aspergillus niger and Trichoderma harzianum. Bulgarian chemical communications, 2017, vol. 49, no. 2, pp. 390-398.

5 Gong W., Cheng Zh., Zhang H., Liu L., Gao P., Wang W. Draft genome sequence of Aspergillus niger strain an76. Genome announcements, 2016, vol. 4, no. 1, pp. 1-2.

6 Cairns T.C., Nai C., MeyerV. How a fungus shapes biotechnology: 100 years of Aspergillus niger research. Fungal Biology and Biotechnology, 2018, vol. 5, no.13, pp. $1-14$.

7 Kubasov K. K., Berstenev C. B., Volkov D. V., Zhambakin K. Zh. Citric acid. Food industry, 2015, vol. 125, no. 3, pp. 121-153.

8 Sazanov K. V. Organicheskie kisloty gribov I ih ekologofiziologicheskoe znachenie. Dokt, Diss [Organic acids of fungi and their ecological and physiological significance. Doct. Diss.]. Saint-Petersburg, 2014. 159 p.

9 Jang J. Y., Choi Y. H., Shin T. S., Kim T. H., Shin K. S., Park H. W., Kim Y. H., Kim H., Choi G. J., Chang K. S., Cha B., Kim I. S., Man A. J., Kim J. C., Biological Control of meloidogyne incognita by Aspergillus niger F22 producing oxalic acid. Plos one, 2016, vol. 11, no. 6, pp. 1-15.

$10 \mathrm{Mu}$ Q., Yue C. T., Hu M., Tian Y. Thermostability improvement of the glucose oxidase from Aspergillus niger for efficient gluconic acid production via computational design. International journal of biological macromolecules, 2019, vol. 139, pp.10601068 .

11 Ramachandran S., Nair S., Larroche C., Pandey A. Gluconic Acid. Current developments in biotechnology and bioengineering, 2017, vol. 9, no. 1, pp. 577-599.

12 Canete-Rodríguez A. M., Santos-Duenas I. M., Jienez-Hornero J. E., Ehrenreich A. L. Gluconic acid: Properties, production methods and applications - an excellent opportunity for agro-industrial by-products and waste bio-valorization. Process biochemistry, 2016, vol. 51, no. 12, pp. 1891-1903.

13 Geyer M., Onyancha F. M., Nicol W., Brink H. G. Malic acid production by Aspergillus oryzae: : the role of $\mathrm{CaCO}_{3}$. Chemical Engineering Transactions, 2018, vol. 70, pp. 1801-1806.

14 Iyyappana J., Bharathirajaa B., Baskarb G., Jayamuthunagaic J., Barathkumara S., Anna R. Malic acid production by chemically induced Aspergillus niger MTCC 281 mutant from crude glycerol. Bioresource technology, 2018. vol. 251, pp. 264-267.

15 Oscar L. D., Elise O., Alexandra B., Bruno B., Pierre V., Jean-Claude S., Eric R., Craig B. F., Laurence L., Anne L. Release of phenolic acids from sunflower and rapeseed meals using different carboxylic esters hydrolases from Aspergillus niger. Industrial crops and products, 2019, vol. 139, pp. 111-579

16 Hossain A. H., Li A., Brickwedde A., Wilms L., Caspers M., Overkamp K., Punt P. J. Rewiring a secondary metabolite pathway towards itaconic acid production in Aspergillus niger. Microbial Cell Factories, 2016, vol. 15, no. 130, pp. 2-15.

$17 \mathrm{Xu}$ Y., Zheng Z., Xu Q., Yong Q., Ouyang J. Efficient conversion of inulin to inulooligosaccharides through endoinulinase from Aspergillus niger. Journal of Agricultural and Food chemistry, 2016, vol. 64, no. 12, pp.782-790.

18 Straat L. Itaconic acid production in Aspergillus niger: PhD thesis. Netherland, 2018. $67 \mathrm{p}$. 
19 Steiger M. G., Rassingerab A., Diethard M., Michael S. Engineering of the citrate exporter protein enables high citric acid production in Aspergillus niger. Metabolic engineering, 2018, vol. 52, pp. 224-231.

20 Show P. L., Oladele K. O., Siew Q. Y., Zakry A. A., Lan J. Ch., Ling T. Ch. Overview of citric acid production from Aspergillus niger. Frontiers in life science, 2015, vol. 8, pp. 271-283.

21 Dewi R., Nur R. M. Antifungal activity of chitosan on Aspergillus spp. International journal of bioengineering and biotechnology, 2018, vol. 2, no. 4, pp. 24-30.

22 Klishanecc E., Lugin V., Litvyak V., Trocckaya T. Hitin-glukanovyi kompleks: poluchenie i svoistva [Chitin-glucan complex: preparation and properties]. Nauka I innovaci [Science and Innovation], 2016, vol. 163, no. 9, pp. 62-68.

23 Princeva A. A., Sharova N. IU., Vybornova T. V. Issledovanie invertaznoi aktivnosti pri izmeneni parametrov processe fermentaci saharozomineralnoi sredy I gidrolizata krahmala mikromicetom Aspergillus niger [Study of invertase activity when changing the parameters of the fermentation process of the sucrose-mineral medium and starch hydrolysate with Aspergillus niger micromycete]. Pishevye sistemy [Food system], 2018, vol. 1, no. 1, pp. 19-23.

24 Aguilar C.N., Gutierrez-Sanchez G. Review: Sources, Properties, Applications and Potential uses of Tannin Acyl Hydrolase. Food Science and Technology International. 2001, vol. 7, no. 5, pp. 373-382.

25 Qiao H., Zhang F., Guan W., Zuo J., Feng D. Optimisation of combi-lipases from Aspergillus niger for the synergistic and efficient hydrolysis of soybean oil. Animal science journal, 2017, vol. 88, pp. 772-780.

26 Santos E. A., Lima A. S., Santana C. F., Soares L. C. Lipase from Aspergillus niger obtained from mangaba residue fermentation: biochemical characterization of free and immobilized enzymes on a sol-gel matrix. Acta scientiarum technology, 2017, vol. 39, no. 1, pp. 1-8.

27 Huang Y., Chen Ch., Huang Ch., Ting-Yung Huang T., Wua T., Cheng Y., Koe T., Lin Ch., Liu J., Guob R. Improving the specific activity of $\beta$-mannanase from Aspergillus niger BK01 by structure-based rational design. Biochimica et biophysica acta, 2014, vol. 1844, pp. 663-669.

28 Uday Sh. P., Bandyopadhyay T. K., Goswami S., Bhunia B. Optimization of physical and morphological regime for improved cellulase free xylanase production by fed batch fermentation using Aspergillus niger (KP874102.1) and its application in biobleaching. Bioengineered, 2016, vol. 8, pp. 137-146.

29 Uday Sh. P., Bandyopadhyay T. K., Bhunia B., Mondal A., Tiwari O., Majumdar R. Isolation, screening and characterization of a novel extracellular xylanase from Aspergillus niger (KP874102.1) and its application in orange peel hydrolysis. International journal of biological macromolecules, 2017, vol. 105, no. 1, pp. 401-409.

30 Reginatto C., Rossi C., Gamba B., Santos M., Meneghel L., Silveira M. M., Malvessi E. Pectinase production by Aspergillus niger LB-02-SF is influenced by the culture medium composition and the addition of the enzyme inducer after biomass growth. Process biochemistry, 2017, vol. 58, pp. 1-8.

31 Ahmed I. A., Zia M. A., Hussain M. A., Akram Z., Naveed M. T., Nowrouzi A. Bioprocessing of citrus waste peel for induced pectinase production by Aspergillus niger; its purification and characterization. Journal of radiation research and applied sciences, 2019, vol. 2, pp. 148-154

32 Ahmed F. A., Ndigwe E. V., Morakinyo S. D., Racheal O. O. Extraction, purification and characterization of protease from Aspergillus niger isolated from yam peels. International journal of nutrition and food sciences, 2015, vol. 4, pp. 125-131. 
33 Enujiugha M. A. Extraction and purification of protease from Aspergillus niger isolation. International journal of nutrition and food sciences, 2018, vol. 4, pp. 125-131. 34 Dabhi U., Rona R., Kumar D. Immobilization and characterization of an alkaline porotease from Aspergillus niger. International journal of multidisciplinary and current research, 2017, vol. 5, pp. 925-929.

35 Smeshko T., Lobanko A., Shtyrov A., Mihalenko E., Belskaya A. Sensory dlya detekci gliukozy v krovi bolnyh diabetom Sensors for detecting glucose in the blood of diabetic patients]. Nauka i Innovaci [Science and Innovation], 2018, vol. 179, no. 1, pp. 73-78.

36 Sun H., Pang M. Improvement of glucoamylase production for raw-starch digestion in Aspergillus niger F-01 by maltose stearic acid ester. Biotechnology letters, 2017, vol. 39, pp. 561-566.

37 Verwoerd T. C., Paridon P. A., Ooyen A., Lent J., Hoekema A., Pen J. Stable accumulation of Aspergillus niger phytase in transgenic tobacco leaves. Gene regulation and molecular genetics. 1995, vol. 109, pp. 1199-1206.

38 Structural formula of inulin. Available at:

https://commons.wikimedia.org/wiki/File:Inulin_strukturformel.png?uselang=ru

(accessed 17 July 2006).

$39 \mathrm{Xu} \mathrm{Y.,} \mathrm{Zheng} \mathrm{Z.,} \mathrm{Xu} \mathrm{Q.,} \mathrm{Yong} \mathrm{Q.,} \mathrm{Ouyang} \mathrm{J.} \mathrm{Efficient} \mathrm{Conversion} \mathrm{of} \mathrm{Inulin} \mathrm{to}$ Inulooligosaccharides through Endoinulinase from Aspergillus niger. Agricultural and Food chemistry, 2016, vol. 64, pp. 2612-2618.

40 Couto S. R., Luis J., Herrera T. Industrial and biotechnological applications of laccases. Biotechnology advances, 2006, vol. 24, pp. 500-513.

41 Dumitresku R. S., Mot A. S. Lakkazy: stroenie fermenynogo kompleksa, kataliziruiushego odnoelektronnuiu reakciu [Laccases: structure of an enzyme complex that catalyzes a single-electron reaction]. Biohimia [Biochemistry], 2013, vol. 78, no. 2, pp. 167-184.

42 Mazotto A. M., Couri S., Damaso M. C., Vermelho A. B. Degradation of feather waste by Aspergillus niger keratinases: Comparison of submerged and solid-state fermentation. International biodeterioration andbiodegradation, 2013, vol. 85. pp. 189195.

43 Kubasov K. K., Berstenev C. B., Volkov D. V., Zhambakin K. Zh. Citric acid. Food industry, 2015, vol. 125, no. 3, pp. 121-153.

44 Nielsen K. F., Mogensen J. M., Johansen M., Larsen T. O., Frisvad J. C. Review of secondary metabolites and mycotoxins from the Aspergillus niger group. Analytical and Bioanalytical Chemistry, 2009, vol. 395, pp. 1225-1242.

45 Han X., Jiang H., Xu J., Zhang J., Li F. Dynamic Fumonisin B2 Production by Aspergillus niger. Toxins, 2017, vol. 9, pp. 2-11.

46 Hasegawa Y., Fukuda T., Hagimori K., Tomoda H., Omura S. Tensyuic Acids, New Antibiotics Produced by Aspergillus niger FKI-2342. Chemical and pharmaceutical bulletin, 2007, vol. 55, pp. 1338-1341.

47 Horeh N. B., Mousavi S. M., Shojaosadati S. A. Bioleaching of valuable metals from spent lithium-ion mobile phone batteries using Aspergillus niger. Journal of power sources, 2016, vol. 320, pp. 257-266.

48 Korostelyova A. B. Sposob ochistki stochnyh vod ot fenolov [Method for treating waste water from phenols], Izvestia, 2011, no. 25, pp. 585-589.

49 Garcı I. C., Pena P.R., Venceslada J. L. B., Martın A. M., Santos M. A., Gomez E. R. Removal of phenol compounds from olive mill wastewater using Phanerochaete chrysosporium, Aspergillus niger, Aspergillus terreus and Geotrichum candidum // Process biochemistry. - 2000. - Vol. 35. - P. 751-758. 
50 Academic Dictionaries and Encyclopedias. Available at: https://dic.academic.ru/dic.nsf/enc_biology/1845/\%D0\%A0\%D0\%BE\%D0\%B4 (accessed 2000).

\title{
ASPERGILLUS NIGER ЗЕН САНЫРАУКҰЛАҚТАРЫНЫҢ БИОЛОГИЯЛЫК БЕЛСЕНДІ ЗАТТАРЫ
}

\author{
Жүрсінәлі А.Б., Кұрманбаев А.А. \\ Ұлттық биотехнология ортальвь \\ Қорвалжын тас жоль, 13/5, Нұр-Сұлтан, 010000, Қазақстан \\ Altynai_9700@mail.ru
}

\section{ТYЙІН}

Aspergillus niger зең саңырауқұлағы ферменттерді, ақуыздарды, ферментативтік өнімдерді және биохимиялық заттарды өндіру үшін өнеркәсіпте қолданылады. 1917 жылы химик Джеймс Карри Aspergillus niger мицелиалды саңырауқұлағының штамын құрамына қант қосылған қоректік ортасында өсіру кезінде жоғары концентрацияда лимон қышқылын алды. Бұл трикарбон қышқылы Кребс циклінің аралық өнімі болып табылады, бұл қышқылды бұрын азық-түлік және сусындар өндірісінде пайдалану үшін цитрус жемістерінен алған. Карри жаңалығы ашылғаннан кейін екі жылдан соң Aspergillus niger арқылы өнеркәсіптік өндіріс басталды, биохимиялық ферментациялық өнеркәсіп өркендей бастады және өнеркәсіптік биотехнология пайда болды. Сонымен қатар Aspergillus niger ақуыздар, ферменттер мен екіншілік метаболиттерді өндіреді. Бұл шолуда Aspergillus niger саңырауқұлағын 100 жылдан астам уақыт бойы биологиялық белсенді заттардың биотехнологиялық өндірісінде және қоршаған ортаны қорғауда пайдалану бойынша материалдар ұсынылған.

Негізгі сөздер: Aspergillus niger, лимон қышқылы, хитин, липаза, ксиланаза, альфа-амилаза, тензио қышқылы.

\section{БИОЛОГИЧЕСКИ АКТИВНЫЕ ВЕЩЕСТВА ПЛЕСНЕВЫХ ГРИБОВ ASPERGILLUS NIGER}

Жүрсінәлі А.Б., Курманбаев А.А.

Национальный центр биотехнологии

Кургальжинское шоссе, 13/5, Нур-Султан, 010000, Казахстан

Altynai_9700@mail.ru

\section{АБСТРАКТ}

Плесневый мицелиальный гриб Aspergillus niger используется для промышленного производства ферментативных продуктов, таких как: ферменты, белки и биохимические вещества. В 1917 году химик Джеймс Карри сделал открытие - штамм мицелиального гриба Aspergillus niger при выращивании в среде с сахаром продуцирует высокие концентрации лимонной кислоты. Эта трикарбоновая кислота является промежуточным продуктом цикла Кребса, ранее ее получали из цитрусовых плодов для использования в производстве продуктов питания и напитков. Через два 
года после открытия Карри началось промышленное производство с использованием $\boldsymbol{A}$. niger, биохимическая ферментационная промышленность начала процветать, и родилась промышленная биотехнология. Также Aspergillus niger производит широкий спектр белков, ферментов и вторичных метаболитов. В обзоре представлены материалы по более чем 100 летнему использованию Aspergillus niger в биотехнологическом производстве биологически активных веществ и охране окружающей среды.

Ключевые слова: Aspergillus niger, лимонная кислота, хитин, липаза, ксиланаза, альфа-амилаза, тензиовая кислота 